UDC 616.155.191-072/.074

DOI: $10.21668 /$ health.risk/2020.3.19.eng

Research article

\title{
ASSESSING RISKS OF DEVELOPING MYELOPROLIFERATIVE DISEASES COMPLICATIONS WITH LASER DOPPLER FLOWMETRY
}

\author{
A.I. Bogomolov ${ }^{1}$, I.L. Davydkin², E.A. Savinov ${ }^{1}$, N.S. Popel'nyuk ${ }^{2}$, K.V. Naumova ${ }^{2}$ \\ ${ }^{1}$ Financial University under the Government of the Russian Federation, 49 Leningradskii Ave., 125993, \\ Moscow, Russian Federation \\ ${ }^{2}$ Samara State Medical University, 89 Chapaevskaya Str., Samara, 443099, Russian Federation
}

Public healthcare in Russia faces many challenges; meeting them requires non-standard and innovative approaches. The set tasks are being solved within the «Public healthcare development» State program. A sub-program within it is called «Development and implementation of innovative diagnostics, prevention, and treatment procedures as well as basics of personified medicine». This sub-program involves wide use of information and digital technologies. Personified medicine envisages developing such methods that would allow early detection of a probable disease even at a preliminary stage in examining a patient; this detection is to be based on a simple and relatively cheap diagnostic technology and to provide a medical center with reliable data on detected signs of a disease for a further diagnosis. Mass use of such technologies also requires truly reliable mathematic procedures and models for putting a preliminary diagnosis. At present cardiovascular diseases are still the leading cause of death all over the world; they develop due to variable factors including influence exerted by malignant neoplasms and also due to chemotherapy.

The paper contains data collected by contemporary medical experts on case histories and complications of myeloproliferative diseases caused by vascular system pathology that holds the first rank place as per mortality worldwide. It was detected that both pathological cellular mass and medications applied to treat myeloproliferative neoplasms could produce adverse effects on vascular endothelium damage to which plays the leading role in cardiovascular continuum. To assess risks of myeloproliferative diseases complications, we examined patients using Laser Doppler Flowmetry (LDF). The results were processed with a logistic regression model. As per ROC-analysis results the obtained diagnostic criterion has sensitivity $(1-\beta)$ and specificity, $(1-\alpha)$ that are equal to 0.87 and 0.96 accordingly, and it means diagnostics is high-quality. The procedure and the mode can be applied in digital medicine.

Key words: digital medicine, diagnostics, myeloproliferative diseases, vascular endothelium dysfunctions, Laser Doppler Flowmetry, mathematical model, logistic regression, risk assessment.

At present the public healthcare system in Russia requires innovative approaches to challenges it has to face. It occurs due to multiple processes such as new diagnostic and treatment techniques being implemented, evolution of infectious agents that cause many diseases, certain socially significant pathologies becoming «younger», issues related to long life span and life quality. Sci- entific society sees a way out of the existing situation in raising availability of highly specialized innovative medicine via widescale practical implementation of new scientific knowledge on what causes a disease, its early diagnostics, treatment techniques as well as due to the very latest information and digital technologies being applied in public healthcare.

(C) Bogomolov A.I., Davydkin I.L., Savinov E.A., Popel'nyuk N.S., Naumova K.V., 2020

Aleksandr I. Bogomolov - Candidate of Technical Sciences, Senior researcher (e-mail: aibogomolov@fa.ru; tel.: +7 (495) 466-61-26, +7 (985) 441-58-46; ORCID: https://orcid.org/0000-0003-3285-0299).

Igor' L. Davydkin - Doctor of Medical Sciences, Professor, Vice-rector responsible for research, Head of the Department for Hospital Therapy with courses in polyclinic therapy and transfusiology (e-mail: dagi2006@rambler.ru; tel.: +7 (846) 264-79-72; ORCID: https://orcid.org/0000-0003-0645-7645).

Evgenii A. Savinov - Candidate of Physical and Mathematical Sciences, Associate Professor (e-mail: easavinov@fa.ru; tel.: +7 (927) 653-13-67; ORCID: https://orcid.org/0000-0001-9414-8820).

Natal'ya S. Popel'nyuk - Candidate of Medical Sciences, assistant (e-mail: gorachaia@live.ru; tel.: +7 (846) 264-79-72; +7 (927) 655-12-60; ORCID: https://orcid.org/0000-0001-6556-2029).

Kseniya V. Naumova - Candidate of Medical Sciences, assistant (e-mail: senechka.naumova@rambler.ru; tel.: +7 (846) 264-79-72, +7 (927) 655-12-60; ORCID: https://orcid.org/0000-0003-3170-1881). 
The outlined tasks are being solved in the RF within «The Public healthcare development» State program (hereinafter called The State Program) ${ }^{1}$. A pilot part of the State Program includes «Public healthcare» National project that has been implemented as per 8 sub-programs starting from 2019. There is a subprogram called «Development and implementation of innovative diagnostics, prevention, and treatment procedures as well as basics of personified medicine»; it envisages wide use of innovative procedures for diagnostics and treatment.

A goal set within the State Program is to reduce mortality caused by cardiovascular diseases down to 450 cases per 100 thousand people by 2024 . Issues related to preventing and treating various microcirculation disorders are among the most significant ones existing in current medical practices. Difficulties in examining microcirculation occur sue to microvessels being too small and vasculatures inside organs having complicated branching structures. At present in the RF various procedures for examining microcirculation in a human body that involve Laser Doppler Flowmetry (LDF) are being implemented in clinical practices. The procedure has some advantages as it is relatively cheap, suitable for use in digital medicine and mass medical examinations with subsequent data transfer into medical centers via telemetry.

Patients who suffer from oncohematological diseases tend to have complications, primarily cardiovascular events, instead of death and disability due to contemporary achievements in medical practices (timely and qualitative diagnostics, target therapy, and monitoring over a patient's state). Endothelial dysfunction (ED) is a pathology related to progressing damage to vessel endothelium that results in its functional disorders [1]. As a result there is a failure in regulation of systems that are responsible for vessels tonus, homeostasis, adhesive cells properties, and vessels neoproliferation due to imbalance between re- laxing and constricting mechanisms and between anti- and pro-coagulant substances production, etc.

Myeloproliferative neoplasms (MPNs) occur due to malignant transformation of pluripotent hemopoietic stem cells in the bone marrow and subsequent clonal proliferation of cells in one or several hemopoiesis branches (erythroid, myeloid, or megakaryocytic one) that are differentiating up to their mature forms [2]. MPNs usually occur in older patients (average age is 55) with their somatic state being significantly burdened with cardiovascular risk factors. Such comorbid states and factors as atherosclerosis, hypertension, metabolic disorders, and unhealthy lifestyle result in much higher risks of cardiovascular disasters among such patients. Research results revealed high frequency of thrombotic complications among people younger than 60 and prevalence of a latent disease at its early stages. Thromboses in arteries prevail regarding localization; they are predominantly acute brain circulation disorders and myocardial infarctions [3]. Mortality due to cerebrovascular diseases is 1.5 times higher among patients with MPNs than among population in general [4].

MPNs include essential thrombocythemia (ET), polycythemia vera (PV), primary myelofibrosis (PMF), and chronic myeloid leukemia (CML).

Polycythemia vera (PV) is an oncohematological myeloproliferative disease that causes a growth in erythrocytes quantity and, consequently, higher blood viscosity which in its turn leads to endothelial dysfunction [5]. Secondary arterial hypertension (AH) occurs in more than half of patients with $\mathrm{PV}$ and is also a risk factor that can cause endothelial dysfunction (ED). Arterial hypertension itself is a most significant medical and social issue. AH occupies one of the first rank places as a cause for cardiovascular complications (strokes, myocardial infarctions, etc.) both in Russia and worldwide [6]. According to several research works, patients

\footnotetext{
${ }^{1}$ The Public healthcare development: the State program of the Russian Federation. The RF Public Healthcare Ministry. Available at: https://www.rosminzdrav.ru/ministry/programms/health/info (20.03.2020) (in Russian).
} 
who suffer from arterial hypertension also have vascular thromboses in $85 \%$ cases and lethal risk is $2-5$ times higher among them [7-9].

A problem for patients with chronic myeloid leukemia (CML) is lifelong necessity to take tyrosine kinase inhibitors (TKI) that influence vascular endothelium and it, in its turn, leads to cardiovascular complications [10-12]. Thus, chemotherapy can be a factor that causes endothelial dysfunction.

Microcirculation disorders and vascular endothelium dysfunctions are still a serious problem for patients with oncohematological diseases. Taking absolute (true) polycythemia and chronic myeloid leukemia as an example we can examine a correlation between pathogenesis of a disease itself and endothelial dysfunction (ED) development. Blood hyperviscosity syndrome that develops due to myeloid proliferation in patients with PV leads to an increase in shear stress on vascular endothelium and endothelial cells and basal membrane becomes disorganized. As a result, mechanisms of endotheliocytes apoptosis, adhesion, and blood cells aggregation become active. Disorders in these mechanisms result in endothelial dysfunction. On the contrary, in case of chronic myeloid leukemia the main role belongs to impacts exerted by TKI medications on vascular endothelium; and by-effects occurring notably in the cardiovascular system are explained by nonselective inhibition of multiple tyrosine kinases. Impacts on normal tyrosine kinases responsible for transferring cell signals lead to endothelial cells dysfunctions [13].

Laboratory procedures based on determining concentrations of substances excreted by endotheliocytes are a golden standard for estimating vascular endothelium functions. These substances include endothelin-1, angiotensinII, von Willebrand factor, nitrogen oxide, NOsynthase, thromboxane, natriuretic peptide, homocysteine, etc. We should also mention some indirect markers showing these damages to vascular endothelium; they are C-reactive protein, fibrinogen, TNF- $\alpha$, concentrations of high density lipoproteins (HDLP), low density lipoproteins (LDLP), and triglycerides.

Many contemporary authors believe that early diagnostics of endothelial dysfunction has a specific role in selecting a strategy for treating patients with various nosologies aimed at slowing down progression of adverse effects in the cardiovascular system [14]. This aspect is being given a lot of attention in up-to-date scientific research. Experts are looking for and developing new procedures for diagnosing endothelial dysfunction at its earliest stages. LDF, nail bed capillaroscopy and bulbar conjunctiva capillaroscopy are the most frequently mentioned techniques in the latest research works $[15,16]$.

In order to perform complex assessment of microcirculatory vessels, experts usually apply a combination of several procedures including LDF, optic tissue oxymetry and pulse oxymetry. Use of different tests performed under loads allows estimating not only compensatory abilities but also early changes in hemodynamics and specific aspects in microvessels functioning in case there is some pathology. These approaches can be successfully applied in practical healthcare for dynamic observations over microcirculatory vessels, ED, and assessing efficiency of treatment procedures selected for each specific patient ${ }^{2}$.

Our research goal was to determine whether it was possible to apply Laser Doppler Flowmetry (LDF) for early detection and assessing risks of cardiovascular complications in patients with myeloproliferative diseases.

Data and methods. We were the first to examine a possibility to diagnose ED at its early stages basing solely on data obtained via LDF [17]. LDF is based on optical sounding of tissues with laser radiation (wave length is $632.8 \mathrm{~nm}$ ) and analysis of scattered and reflected radiation from moving erythrocytes. Laser radiation reflection from erythrocytes that move in microvessels results in changes in a signal frequency and it allows determining various microcirculation properties (Figure 1).

\footnotetext{
${ }^{2}$ Laser Doppler Flowmetry to examine blood microcirculation. Guide for doctors. In: A.I. Krupatkin, V.V. Sidorov eds. Moscow, Meditsina Publ., 2005, 256 p. (in Russian).
} 


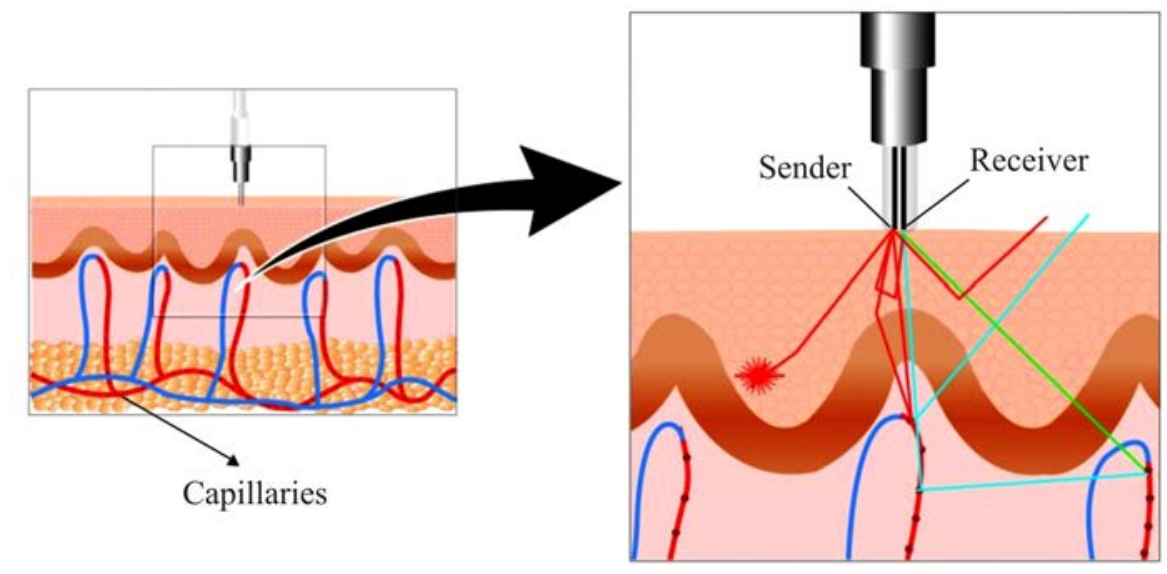

Figure 1. Laser Doppler Flowmetry (LDF) procedure

The procedure has some basic advantages such as simplicity, safety, and cheapness in comparison with expensive invasive ones. Additional motivation to use LDF is a possibility to diagnose ED at its early stage, that is, before any cardiovascular complications have developed. It is possible due to the microcirculatory system being one of the most rapidly reacting to effects produced by pathologic factors [18].

Recently computer technologies and mathematical models have been widely used to put a diagnosis as per results of examinations performed on patients. There is a wide range of mathematical models and computer programs that allow modeling heart and cardiovascular system functioning. For example, there are graph models, difference equations systems, hemodynamics equations, non-linear econometric models, image identification procedures, and artificial intelligence procedures [19-23]. Logistic regression was previously applied in diagnosing ED; however, we haven't been able to find data on its application for predicting complications in patients with myeloproliferative neoplasms in available literature sources ${ }^{3}$.

Then we come to examining predictive properties of the regression model that includes 12 parameters (Table 1) measured with LDF procedure performed with Lakk-OP laser microcirculation analyzer.
Overall, 143 patients were examined; 103 out of them had myeloproliferative neoplasms (absolute (true) polycythemia and chronic myeloid leukemia). These nosologies were verified with laboratory-instrumental procedures according to the existing recommendations [24, 25]. In order to determine endothelial dysfunctions, we quantitatively determined endothelin-1 in blood serum and patients with MPNs with endothelin-1 concentration being higher than $1.37 \mathrm{fmol} / \mathrm{L}$ were assigned into a group with ED signs.

Our reference group was made up of 40 practically healthy people comparable in terms of age and sex. In order to exclude influence exerted by any concomitant pathology on vessels endothelium, we didn't include patients with chronic heart failure, stages II and III (classified as per Strazhesko-Vasilenko), clinically significant IHD, other symptomatic arterial hypertension, acute cerebral circulation disorders and myocardial infarction during 6 months prior to the research, chronic bronchopulmonary pathology, pancreatic diabetes, inflammatory diseases of the connective tissue, and smoking patients.

Results and discussion. We applied a logistic regression model to estimate probability of ED that could cause cardiovascular complications in the examined patients [26].

\footnotetext{
${ }^{3}$ Kurapova M.V. Clinical and diagnostic significance of endothelial dysfunction in patients with chronic kidney disease. thesis. ... for Candidate of Medical Sciences degree. Samara, 2015, 24 p. (in Russian).
} 
Table 1

Microcirculation parameters

\begin{tabular}{|c|l|c|}
\hline $\begin{array}{c}\text { MC } \\
\text { parameter }\end{array}$ & \multicolumn{1}{|c|}{ Description } & Variable \\
\hline M & Average perfusion & $X_{1}$ \\
\hline Kv & Blood flow variation coefficient & $X_{2}$ \\
\hline $\begin{array}{c}\text { Am/BFR } \\
\text { (blood flow rate) }\end{array}$ & $\begin{array}{l}\text { Standardized amplitude of micro blood flow fluctuations associated with } \\
\text { myogenic microvessels regulation }\end{array}$ & $X_{3}$ \\
\hline Sm & Perfusion oxygen saturation index & $X_{4}$ \\
\hline RCBF & Reserve capillary blood flow & $X_{5}$ \\
\hline An/BFR & $\begin{array}{l}\text { Standardized amplitude of micro blood flow fluctuations associated with } \\
\text { neurogenic microvessels regulation }\end{array}$ & $X_{6}$ \\
\hline Ae/BFR & $\begin{array}{l}\text { Standardized amplitude of micro blood flow fluctuations associated with } \\
\text { endothelial microvessels regulation }\end{array}$ & $X_{7}$ \\
\hline I & Index of specific oxygen consumption in tissue & $X_{8}$ \\
\hline D2 & Correlation dimension & $X_{9}$ \\
\hline Ho & Relative entropy & $X_{10}$ \\
\hline R/S & Hurst parameter & $X_{11}$ \\
\hline BTI & Breath test index & $X_{12}$ \\
\hline
\end{tabular}

Our initial sampling was divided into a training one and a test one. $60 \%$ people were randomly selected to be included into the training sampling; overall, there were 86 people in it, 71 out of them with pathology and 15 people being a reference group. The remaining 57 people ( 32 patients with pathology and 25 being a reference group) were included into the test sampling.

Hereinafter we use the following legend: $N$ is the training sampling volume, $K=12$ is a number of parameters, vector of parameters that are attributed to a case with the number $\mathrm{n}$

$$
\vec{X}_{n}=\left(X_{1 n}, \ldots, X_{K n}\right), n=\overline{1, N},
$$

ed is an indicator showing there is endothelium dysfunciton (hereinafter pathology) that can be equal to 0 or 1 .

We assume that dependence between pathology probability and the vector of parameters can be given with the following equation:

$$
P\left\{e d=1 \mid \vec{X}_{n}\right\}=f\left(Y_{\beta}^{*}\left(\vec{X}_{n}\right)\right),
$$

where

$$
Y_{\beta}^{*}\left(\vec{X}_{n}\right)=\beta_{0}+\sum_{k=1}^{K} \beta_{k} X_{k n}
$$

is a linear combination of microcirculation parameters with beta coefficients,

and

$$
f(y)=\frac{1}{1+e^{-y}}
$$

is a logistic function. A solution to a task of logarithmic likelihood fucntion maximization

$$
\begin{aligned}
& L(\beta)=\sum_{n=1}^{N} j_{n} \ln f\left(Y_{\beta}^{*}\left(\vec{X}_{n}\right)\right)+ \\
& +\left(1-j_{n}\right) \ln \left(1-f\left(Y_{\beta}^{*}\left(\vec{X}_{n}\right)\right)\right)
\end{aligned}
$$

is a vector of regression coefficients

$$
\hat{\beta}=\arg \max _{\beta} L(\beta) .
$$

ED-index concept was introduced as statistics of classification criterion:

$$
\text { ed.index }(\vec{X})=f\left(\hat{\beta}_{0}+\sum_{k=1}^{5} \hat{\beta}_{k} X_{k}\right)
$$


Table 2

Significant MC parameters and relevant regression coefficients

\begin{tabular}{|c|c|c|c|c|c|c|}
\hline $\begin{array}{c}\text { MC } \\
\text { parameter }\end{array}$ & Variable & $\begin{array}{c}\text { Mean, standard error } \\
\text { of the mean } \\
\text { (pathology) }\end{array}$ & $\begin{array}{c}\text { Mean, standard error } \\
\text { of the mean } \\
\text { (reference group) }\end{array}$ & $\begin{array}{c}\text { Regression } \\
\text { coefficient }\end{array}$ & $\begin{array}{c}\text { Standard error of } \\
\text { coefficient }\end{array}$ & p-value \\
\hline $\mathrm{M}$ & $X_{1}$ & $15,73 \pm 0,72$ & $18,44 \pm 0,34$ & $\hat{\beta}_{1}=-0,996$ & 0.285 & 0.00065466 \\
\hline $\mathrm{Kv}$ & $X_{2}$ & $6,38 \pm 1,01$ & $9,08 \pm 0,73$ & $\hat{\beta}_{2}=-0,628$ & 0.153 & 0.00007332 \\
\hline $\mathrm{Am} / \mathrm{BFR}$ & $X_{3}$ & $0,42 \pm 0,02$ & $0,51 \pm 0,02$ & $\hat{\beta}_{3}=-10,014$ & 3.670 & 0.00724567 \\
\hline $\mathrm{Sm}$ & $X_{4}$ & $4,29 \pm 0,80$ & $5,14 \pm 0,27$ & $\hat{\beta}_{4}=-1,027$ & 0.324 & 0.00190552 \\
\hline $\mathrm{RCBF}$ & $X_{5}$ & $143,81 \pm 7,60$ & $129,41 \pm 2,01$ & $\hat{\beta}_{5}=0,061$ & 0.041 & 0.01402911 \\
\hline & & & & $\hat{\beta}_{0}=25,001$ & 9.833 & 0.01218424 \\
\hline
\end{tabular}

At the first stage all the variables were included into analysis; the most significant ones were determined with reverse exclusion. Then, to provide the maximum precise classification, the variables were first excluded in different combinations at the second stage. At the third stage the variables that were excluded at the first stage were included again. Each time a new model was compared with the first one via ROC curve analysis. As a result, the best model included five variables (Table 2).

ROC curves were applied to estimate quality of diagnostics, to select threshold for ED-index, and to make comparisons between different models. The threshold classifier value $c=0.887$ was obtained basing on a condition of achieving maximum sum of sensitivity and specificity. As per ROC analysis results the obtained diagnostic criterion for the test sampling had sensitivity $(1-\beta)$ and specificity $(1-\alpha)$ equal to 0.875 (28 truly positive results out of 32) and 0.96 (24 truly positive results out of 25) accordingly. Square (SUC) under ROC curve (Figure 2) amounted to 0.96 and it was close to the excellent classification quality (significance of the model was the following: $\mathrm{p}<10 \mathrm{E}-5)$.

Therefore, regarding hypothesis testing theory, ED-index was applied as statistics of testing criterion for a zero hypothesis that there was no pathology. A condition for selecting a threshold value was equivalent to selecting Bayesian criterion among criteria with the said statistics that had a value equal to 0.875 at significance level being 0.04 .

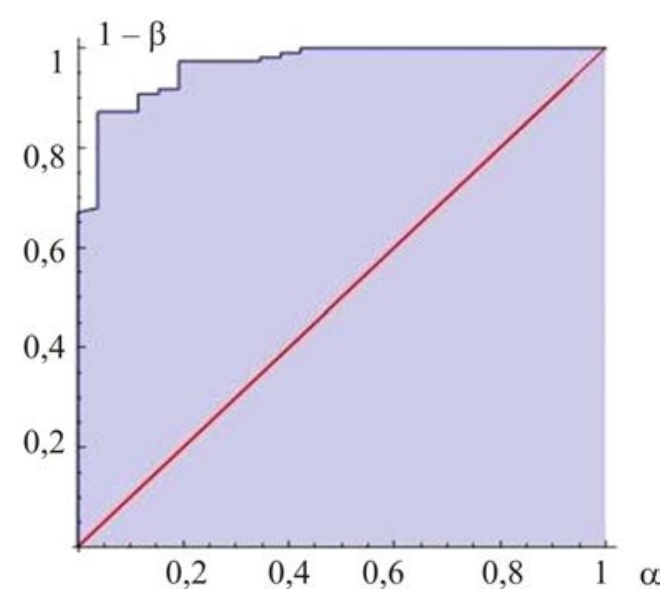

Figure 2. ROC curve

The ultimate probability estimation was determined as piecewise-linear transformation of ED-index in order to reduce a threshold value to an expected one equal to 0.5 :

$$
P^{*}=g(\text { ed.index })
$$

where

$$
g(x)= \begin{cases}\frac{x}{2 c}, & 0 \leqslant x<c \\ \frac{x+1-2 c}{2(1-c)}, & c \leqslant x \leqslant 1\end{cases}
$$

Therefore, a certain value $P^{*}>0,5$ corresponded to any ED-index value calculated with the model and being higher than the selected threshold value $c=0,887$.

When considering the most significant parameters in the model separately (with relevant coefficients of significance being lower than 0.005), one should note that a classification 
that separately rested on each of the said parameters with the same criterion for selecting a threshold value showed lower results (Table 3) than the model under consideration.

Table 3

Quality of one-dimensional models

\begin{tabular}{|c|c|c|c|}
\hline $\begin{array}{c}\text { MC } \\
\text { parameter }\end{array}$ & Sensitivity & Specificity & SUV \\
\hline $\mathrm{M}$ & 0.72 & 0.68 & 0.76 \\
\hline $\mathrm{KV}$ & 0.875 & 0.56 & 0.76 \\
\hline $\mathrm{Sm}$ & 0.69 & 0.72 & 0.69 \\
\hline
\end{tabular}

A software package was developed basing on the obtained research results and a copyright certificate for it was issued.

Conclusion. Procedures for non-invasive differential diagnostics of microcirculatory and main-line vessels pathology based on the latest technologies are given a lot of attention due to multiple reasons. Microcirculatory vessels as a component in the whole circulatory system are rather vulnerable as per their structure and functions to external and/or internal threats. Statistic data collected worldwide clearly indicate that morbidity and mortality caused by cardiovascular pathology hold the first rank place. LDF is an up-to-date non-invasive procedure for assessing microcirculation functioning. The procedure is highly sensitive and manages to grasp subtle changes in microcirculatory blood flow.

The obtained results allow concluding that LDF and the developed regression model have high diagnostic efficiency for early detection and assessment of cardiovascular risks in patients suffering from myeloproliferative diseases.

Funding. The research was not granted any sponsor support.

Conflict of interests. The authors declare there is no any conflict of interests.

\section{References}

1. Taddei S., Ghiadoni L., Virdis A., Versari D., Salvetti A. Mechanisms of endothelial dysfunction: clinical significance and preventive non-pharmacological therapeutic strategies. Curr. Pharm. Des, 2003, vol. 9, no. 29, pp. 2385-2402. DOI: 10.2174/1381612033453866

2. Aleksandrova T.N., Yadrikhinskaya V.N., Mulina I.I., Solov'eva I.E., Terekhova L.D., Pavlova N.I., Zhozhikov L.R., Kurtanov Kh.A. Cardiovascular risk factors in patients with chronic myeloproliferative diseases. Vestnik severo-vostochnogo federal'nogo universiteta imeni M.K. Ammosova. Seriya «Meditsinskie nauki», 2018, vol. 13, no. 4, pp. 28-32 (in Russian). DOI: 10.25587/SVFU.2018.4(13).20741

3. Melikyan A.L., Sukhanova G.A., Vakhrusheva M.V., Subortseva I.N., Orel E.B. Experience in treating portal thromboses in patients with chronic myeloproliferative diseases. Ter Arkh, 2016, vol. 88, no. 1, pp. 89-95. DOI: 10.17116/terarkh201688189-95

4. Tanashyan M.M., Kuznetsova P.I., Raskurazhev A.A., Lagoda O.V. Nekotorye aspekty profilaktiki narushenii mozgovogo krovoobrashcheniya $u$ patsientov s mieloproliferativnymi zabolevaniyami [Certain aspects in preventing brain circulation disorders in patients with myeloproliferative diseases]. Medicamente. Lechim s umom, 2017, vol. 3, no. 1, pp. 41-44 (in Russian).

5. Melikyan A.L., Turkina A.G., Abdulkadyrov K.M., Zaritskii A.Yu., Afanas'ev B.V., Shuvaev V.A., Lomaia E.G., Morozova E.V. [et al.]. Clinical recommendations for diagnosis and therapy of Ph-negative myeloproliferative diseases (polycythemia vera, essential thrombocythemia, primary myelofibrosis). Gematologiya i transfuziologiya, 2014, vol. 59, no. 4, pp. 31-56 (in Russian).

6. Disfunktsiya endoteliya i arterial'naya gipertenziya [Endothelium dysfunction and arterial hypertension]. In: P.A. Lebedeva ed. Samara, OFORT Publ., 2010, 192 p. (in Russian).

7. Fudashkin A.A. Endothelial disfunction in patients with hypertension and history of ischemic stroke. Vestnik Kyrgyzsko-Rossiiskogo Slavyanskogo universiteta, 2015, vol. 15, no. 4, pp. 173-175 (in Russian).

8. Clark C.E., Taylor R.S., Shore A.C., Ukoumunne O.C., Campbell J.L. Association of a difference in systolic blood pressure between arms with vascular disease and mortality: a systematic review and meta-analysis. Lancet, 2012, vol. 379, no. 9819, pp. 905-916. DOI: 10.1016/S01406736(11)61710-8 
9. Vlachopoulos C., Aznaouridis K., O’Rourke M.F., Safar M.E., Baou K., Stefanadis C. Prediction of cardiovascular events and allcause mortality with central haemodynamics: a systematic review and meta-analysis. Eur. Heart. J., 2010, vol. 31, no. 15, pp. 1865-1871. DOI: 10.1093/eurheartj/ehq024

10. Duangnapasatit D., Rattarittamrong E., Rattanathammethee T., Hantrakool S., Chai-Adisaksopha C., Tantiworawit A., Norasetthada L. Clinical Manifestations and Risk Factors for Complications of Philadelphia Chromosome-Negative Myeloproliferative Neoplasms. Asian. Pac. J. Cancer Prev., 2015, vol. 16, no. 12, pp. 5013-5018. DOI: 10.7314/apjcp.2015.16.12.5013

11. Steegmann J.L., Baccarani M., Breccia M., Casado L.F., García-Gutiérrez V., Hochhaus A., Kim D.-W., Kim T.D. [et al.]. European Leukemia Net recommendations for the management and avoidance of adverse events of treatment in chronic myeloid leukaemia. Leukemia, 2016, vol. 30, no. 8, pp. 1648-1671. DOI: 10.1038/leu.2016.104

12. Popova A.A., Berezikova E.N., Mayanskaya S.D. Mechanism of endothelial dysfunction development. Sibirskoe meditsinskoe obozrenie, 2010, vol. 64, no. 4, pp. 7-11 (in Russian).

13. Orphanos G.S., Ioannidis G.N., Ardavanis A.G. Cardiotoxity induced by tyrosine kinase inhibitors. Acta Oncologica, 2009, vol. 48, no. 7, pp. 964-970. DOI: 10.1080/02841860903229124

14. Bulaeva N.I., Golukhova E.Z. Endothelial dysfunction and oxidant stress: the role in cardiovascular pathology. Kreativnaya kardiologiya, 2013, no. 1, pp. 14-22 (in Russian).

15. Ivanov A.N., Grechikhin A.A., Norkin I.A., Puchin'yan D.M. Methods of endothelial dysfunction diagnosis. Regionarnoe krovoobrashchenie i mikrotsirkulyatsiya, 2014, vol. 52, no. 4, pp. 4-11 (in Russian).

16. Kanishcheva E.M., Fedorovich A.A. Possibilities for evaluating the condition of miscrovasculature and walls of large blood vessels. Serdtse: zhurnal dlya praktikuyushchikh vrachei, 2010, vol. 9, no. 1 (51), pp. 65-70 (in Russian).

17. Khalepo O.V., Molotkov O.V., Eshkina S.L. Otsenka sostoyaniya sistemy mikrotsirkulyatsii i mekhanizmov regulyatsii tkanevogo krovotoka u bol'nykh pri razlichnykh variantakh IBS metodom funktsional'nykh nagruzochnykh prob [Assessing microcirculation functioning and mechanisms of tissue circulation regulation in patients suffering from various types of IHD via functional tests under loads]. Regionarnoe krovoobrashchenie i mikrotsirkulyatsiya, 2007, vol. 6, no. 3 (23), pp. 43-46 (in Russian).

18. Bogoyavlenskii V.F., Bogoyavlenskaya O.V. Clinical aspects of microcirculation research: achievements and perspectives. Kazanskii meditsinskii zhurnal, 2011, vol. 92, no. 2, pp. 145-151 (in Russian).

19. Favorskii A.P., Abakumov M.V., Esikova N.B., Mukhin S.I., Sosnin N.V. Matematicheskaya model' serdechno-sosudistoi sistemy. Preprint [A mathematical model for the cardiovascular system. Pre-print]. Moscow, MGU Publ., 1998, 16 p. (in Russian).

20. Abakumov M.V., Ashmetkov I.V., Esikova N.B., Koshelev V.B., Mukhin S.I., Sosnin N.V., Tishkin V.F., Favorskii A.P., Khrulenko A.B. Metodika matematicheskogo modelirovaniya serdechno-sosudistoi sistemy [Mathematical techniques for cardiovascular system modeling]. Matematicheskoe modelirovanie, 2000, vol. 12, no. 2, pp. 106-117 (in Russian).

21. Ashmetkov I.V., Mukhin S.I., Sosnin N.V., Favorskii A.P., Khrulenko A.B. Chastnye resheniya uravnenii gemodinamiki. Preprint [Particular solutions to hemodynamics equations. Pre-print]. Moscow, Dialog-MGU Publ., 1999, 43 p. (in Russian).

22. Bunicheva A.Ya., Mukhin S.I., Sosnin N.V., Favorskii A.P. Osrednennaya nelineinaya model' gemodinamiki v odnom sosude. Preprint [Averaged non-linear model showing hemodynamics in one vessel. Pre-print]. Moscow, Dialog-MGU Publ., 2000, 21 p. (in Russian).

23. Gusev A.V., Kuznetsova T.Yu., Korsakov I.N. Iskusstvennyi intellect v otsenke riskov razvitiya serdechno-sosudistykh zabolevanii [Artificial intellect in assessing risks of cardiovascular diseases development]. Zhurnal telemeditsiny i elektronnogo zdravookhraneniya, 2018, no. 3, pp. 18-32 (in Russian).

24. Turkina A.G., Zaritskii A.Yu., Shuvaev V.A., Chelysheva E.Yu., Lomaia E.G., Morozova E.V., Golenkov A.K., Pospelova T.I. [et al.]. Clinical Recommendations for the Diagnosis and Treatment of 
Chronic Myeloid Leukemia. Klinicheskaya onkogematologiya, 2017, vol. 10, no. 3, pp. 294-316 (in Russian).

25. Melikyan A.L., Kovrigina A.M., Subortseva I.N., Shuvaev V.A., Ageeva T.A., Baikov V.V., Vinogradova O.Y., Golenkov A.K. [et al.]. National clinical recommendations for diagnosis and therapy of PH-negative myeloproliferative neoplasms (polycythemia vera, essential thrombocythemia, primary myelofibrosis) (edition 2018). Gematologiya i transfuziologiya, 2018, vol. 63, no. 3, pp. 275-315 (in Russian).

26. Hosmer D.W., Lemeshow S., Sturdivant R.X. Applied logistic regression. USA, John Wiley \& Sons, Inc. Publ., 2013, 527 p.

Bogomolov A.I., Davydkin I.L., Savinov E.A., Popel'nyuk N.S., Naumova K.V Assessing risks of developing myeloproliferative diseases complications with laser doppler flowmetry. Health Risk Analysis, 2020, no. 3, pp. 159-167. DOI: 10.21668/health.risk/2020.3.19.eng

Received: 05.06.2002

Accepted: 18.09 .2020

Published: 30.09 .2020 